\title{
КОМПЛЕКСНА БАГАТОРІВНЕВА СИСТЕМА МЕДИКО-СОЦІАЛЬНОЇ ПРОФІЛАКТИКИ ВЖИВАННЯ ПСИХОАКТИВНИХ РЕЧОВИН У ДІТЕЙ ТА ПІДЛІТКІВ ЯК БАЗА СУЧАСНИХ МЕДИЧНИХ ОСВІТНІХ ПРОГРАМ У ЦИХ НАПРЯМКАХ
}

\author{
А. М. Вісвський
}

Український медичний та моніторинговий центр з алкоголю та наркотиків МОЗ України

\section{THE COMPREHENSIVE MULTIDIMENSIONAL MEDICAL AND SOCIAL SUBSTANCE USE PREVENTION SYSTEM FOR CHILDREN AND ADOLESCENTS: AS A BASIS FOR CONTEMPORARY MEDICAL EDUCATION}

\author{
A. M. Viyevskyi \\ Ukrainian Medical and Monitoring Centre on Alcohol and Drugs of MPH of Ukraine
}

\begin{abstract}
У роботі висвітлені ідеологія та структура розробленої та апробованої в пілотних регіонах - Чернівецькій, Закарпатській, Київській областях та м. Києві - комплексної багаторівневої системи медико-соціальної профілактики вживання психоактивних речовин у дітей та підлітків, яка спрямована на формування в учнів відповідального ставлення до власного здоров'я у профілактичній співпраці з їх батьками та персоналом школи, що базується на навчанні здорового способу життя на засадах розвитку життєвих навичок та створення можливостей впливу на основні негативні наслідки вживання дітьми ПАР, а саме - вживання зі шкідливими наслідками, що досягасться впливом в різних напрямках профілактичної роботи: оріснтованої безпосередньо на дитячі контингенти (диференційовані залежно від вікової групи), на їх батьків та персонал загальноосвітніх шкіл.
\end{abstract}

The article describes the philosophy and structure of the new comprehensive multidimensional medical and social substance use prevention system for school children and adolescents population, firstly tried in the pilot sites in the city of Kyiv and Chernivtsi, Transcarpathian and Kyiv region. The prevention system's goal is to develop the pupils' self-responsible healthy style position based on their cooperation with parents and teachers in the frames of implemented prevention program. At the same time the system is elaborated to upgrade the potential to influence the most actual concequences of the children's psychoactive substances use, the harmful use, first of all. The integrated prevention activities combine the direct interventions for school children contingents, parents and school staff.

Вступ. У 2010 році закінчився термін дії Програми реалізації державної політики у сфері боротьби 3 незаконним обігом наркотичних засобів, психотропних речовин і прекурсорів на 2003 - 2010 роки. Результати та досягнення програми опрацьовуються MBC. В кінці 2010 року за дорученням Кабінету Міністрів України було розроблено Концепцію реалізації державної політики у сфері протидії поширенню наркоманії, боротьби з незаконним обігом наркотичних засобів, психотропних речовин та прекурсорів на 2011-2015 роки (далі - Концепція). На відміну від попередньої, Концепція 2011-2015 pр. не передбачає створення програми, а обмежується планом заходів. Фінансування заходів щодо реалізації Концепції здійснюється в межах бюджетних призначень, передбачених на відповідний рік міністерствам та іншим центральним органам виконавчої влади, до повноважень яких належить вирішення питань у сфері обігу наркотичних засобів, психотропних речовин та прекурсорів, реабілітації та реінтеграції в суспільство осіб з наркотичною залежністю, проведення інформаційної політики в зазначеній сфері. Узагальнення матеріалів щодо виконання плану заходів покладено на Державний комітет 3 питань контролю за наркотиками (3 06.04.2011 p. - Державна служба України з контролю за наркотиками). В цілому Концепція передбачає розвиток наркополітики за такими напрямками:

- координація дій органів виконавчої влади. Створення системи обміну інформації, пов'язаної з обігом наркотичних засобів, психотропних речовин та прекурсорів, а також лікарських засобів, зловживання якими може викликати наркотичну залежність;

(c) А. М. Вієвський 
- зменшення попиту та вживання наркотичних засобів, проведення дієвої первинної профілактики серед дітей та молоді. Підвищення рівня поінформованості населення щодо наслідків розповсюдження наркотиків;

- підвищення ефективності органів виконавчої влади у сфері протидії незаконному обігу наркотиків. Підвищення рівня контролю за легальним обігом психоактивних речовин (ПАР) та прекурсорів;

- вдосконалення механізмів моніторингу та створення загальнодержавної системи наукового аналізу ризиків, аналізу оцінки ефективності заходів;

- підвищення ефективності заходів з лікування та реабілітації залежних на наркоманію.

Як бачимо, створення системи дієвої первинної профілактики вживання ПАР серед дітей та підлітків є одним 3 важливіших напрямків державної наркотичної політики.

Основна частина. На сьогодні профілактичні дії щодо наркотичних/алкогольних проблем серед дітей та молоді є частиною стратегї формування здорового способу життя на засадах розвитку життєвих навичок та координуються Міністерством освіти та науки, молоді та спорту України.

Дії первинної профілактики зосереджені в школі. На сьогодні обов'язковим навчальним предметом, в рамках якого розглядаються теми щодо профілактики ризикової поведінки, є інтегрований курс “Основи здоров’ я”. Результати моніторингового дослідження курсу свідчать [1], що за вісім років упровадження предмета лише 47,7 \% вчителів мають сертифікат про проходження курсової підготовки з методики викладання предмета. 51 \% учнів оволоділи 8 навичками, що сприяють безпеці в навколишньому середовищі, у 49 \% респондентів - навички сформовані недостатньо. Проте відсутні аналітичні дані стосовно оцінки сформованості в учнів соціальних і психологічних навичок, необхідних для попередження появи наркотичних проблем. Батьківські збори виявились найбільш відвідуваним заходом профілактичної взаємодії з батьками в порівнянні з тренінгами, лекціями, бесідами, спортивними змаганнями.

Крім обов'язкових уроків у загальноосвітніх навчальних закладах реалізуються факультативні курси: програма “Сприяння просвітницькій роботі “"рівний-рівному” серед молоді щодо здорового способу життя; програма "Корисні звички” (1-4 класи); програма “Я - моє здоров'я - моє життя” (5-6 класи); програма “Школа проти СНІДу” (10-11 класи); програма “Культура життєвого самовизначення" (5-9 класи).

В країні популяризується волонтерський рух та лідерство за методикою “рівний-рівному”. Наразі $є$ недостатнє фінансування мережі “Школи волонтерів”, слабка навчально-методична база, складнощі у роботі з волонтерами у сільській місцевості. Проте дослідження свідчать про активізацію роботи 3 популяризації здорового способу життя серед молоді. Дослідники визначили, що молодь цікавиться різнобічною волонтерською роботою, зокрема формуванням здорового способу життя та благодійністю [2].

Профілактичні проекти/програми в полі вибіркової профілактики (тобто профілактики, спрямованої на дітей та молодь, які внаслідок біологічних, психологічних або соціальних причин перебувають в обставинах, що сприяють вживанню спиртних напоїв чи наркотичних речовин, i має на меті попередження їх залучення до вживання психоактивних речовин) реалізуються здебільшого через мережу спеціалізованих центрів, соціальних служб, мобільних консультативних пунктів, “клінік дружніх до молоді”, служб телефону довіри, аптек. Окремі профілактичні проекти ініціюються недержавними організаціями за фінансової підтримки міжнародних донорів. Так, спеціалісти проекту “Профілактика ВІЛ/СНІДу та пропаганда здорового способу життя серед дітей вулиці” створили серію навчальних мультиплікаційних фільмів “Невигадані історіі” на основі реальних історій та за допомогою дітей і підлітків, які більшість свого часу проводять на вулиці. Профілактичні інтервенції в рамках цього проекту включають питання попередження вживання ПАР та формування здорового способу життя [3].

За останні роки в країні розроблена та впроваджена низка стандартів для окремих видів соціальних послуг, зокрема: сім'ям, які опинилися в складних життєвих обставинах; вживачам ПАР, в тому числі споживачам ін'єкційних наркотиків, i їх близькому оточенню; ресоціалізації осіб, які повернулися з місць позбавлення волі; соціальної адаптації випускників інтернатних закладів для дітей-сиріт і дітей, позбавлених батьківського піклування; профілактики ВІЛ/ ІПСШ та ускладнень, що є супутніми при вживанні ін'єкційних наркотиків; реінтеграції бездомних громадян; соціально-медичних послуг для молоді, що надаються на базі дружніх клінік для молоді. Стандарти визначають основні вимоги до рівня якості, процесу, змісту, обсягу, процедур та ресурсів надання послуг, визначають перелік закладів та установ, які можуть надавати такі послуги.

У реалізації найбільш значимих програм/проектів зазвичай беруть участь багато співвиконавців 3 числа державних та недержавних установ та організацій. Однак єдиної системи збору, аналізу, оцінки та моніто- 
рингу профілактичних дій серед загального населення та окремих його груп на сьогодні в країні не існує.

Результати досліджень щодо розповсюдження вживання ПАР серед учнівської молоді в Україні доводять недостатню ефективність існуючих профілактичних заходів.

Так, нами, для ідентифікації патернів дитячої та підліткової алкогольної та наркотичної поведінки та встановлення мішеней профілактичного впливу, нами проведено опитування та анкетування дитячих контингентів - учнів шкіл Чернівецької, Київської, Закарпатської областей та м. Києва (кількість обстежених - 1870 осіб). Кількість респондентів розраховувалась відповідно до загальної кількості дитячо-підліткового населення в регіоні, що достовірно відображало закономірності генеральної сукупності. Даний регіональний розподіл був обгрунтований різними рівнями ураженості наркологічними проблемами серед дитячо-підліткового населення (низький - Чернівці, Закарпаття; середній - Київська область; високий - м. Київ).

За результатами дослідження, які виявились конгруентними до інших соціологічних опитувань [4,5], виявилось, що $91 \%$ опитаних учнів віком 15-16 років хоча б один раз у житті вживали алкогольні напої. Найбілыш вживанимиі доступними напоями для учнівської молоді єпиво, вино та шампанське. Так, про вживання пива протягом останніх 30 днів до проведення дослідження зазначили $63 \%$ учнів, про вживання вина або шампанського $41 \%$. Вживання домашніх міцних алкогольних напоїв становить $7 \%$, домашнього вина - $26 \%$.

Перший досвід вживання пива $16 \%$ респондентів мали у віці 9 років. У цьому ж віці $12 \%$ учнів перший раз спробували вино або шампанське та 4 \% учнів спробували міцні алкогольні напої. Алкогольні коктейлі 3 вмістом алкоголю до 5 \% (наприклад "Ром-кола", “Джин-тонік”, “Longer”, "Shake”) - 14\% учнів почали вживати ще не досягнувши 14 років.

Щодо ймовірності наслідків вживання алкоголю, виявилося, що 27 \% хлопців та 28 \% дівчат оцінюють “шкоду для здоров’ я” як абсолютно неможливу у разі вживання ними алкоголю. Ймовірність “позитивних наслідків" вживання алкоголю, а саме почуття "розслабленості”, відзначають 57 \% хлопців та 50 \% дівчат. Можливість “забути про свої проблеми” як дуже ймовірну відзначають 37 \% хлопців та 39 \% дівчат.

3 усіх наркотичних речовин, які вживає молодь, найбільш поширеними виявились марихуана та гашиш. 7,9 \% учнівської молоді вживали марихуану 1-2 рази впродовж життя, а 0,8 \% - вживали 40 і більше разів. Також результати свідчать про досить істотне збілышення вживання дискотечного наркотику екстазі.

Істотно зросла в останні роки частка тих, хто долучився до першого вживання марихуани або гашишу у юному віці. Навіть у віці до 9 років марихуану або гашиш вперше спробували $1,3 \%$ хлопців та 0,4 \% дівчат. Так, за даними дослідження, у віці 15 років хлопці значно частіше за дівчат (7,1 \% проти 3,5 \%) починають вживання марихуани або гашишу.

Найпоширенішим механізмом отримання першого наркотику молоддю є пропозиція спробувати його у референтній групі (компанії друзів і знайомих). Основним визначальним мотивом спробувати наркотичну речовину виявилась цікавість - як для хлопців (7 \%), так і для дівчат (4\%). Досить поширеним мотивом початку вживання наркотиків є також надлишок вільного часу. 3 цієї причини вживали наркотичні речовини $2 \%$ хлопців та $1 \%$ дівчат. Практично така ж сама частка респондентів повідомила, що вони не хотіли виділятися 3 компанії (1,7 \% хлопців та 0,7 \% дівчат).

3 урахуванням вищенаведеного, на базі світового досвіду та результатів власних досліджень, нами створена комплексна багаторівнева система медико-соціальної профілактики вживання ПАР у дітей та підлітків, апробована та впроваджена в школах Чернівецької, Київської, Закарпатської областей та м. Києва, основна ідея якої - сформувати в учнів відповідальне ставлення до власного здоров' я у профілактичній співпраці з їх батьками та персоналом школи, що базується на навчанні здорового способу життя на засадах розвитку життєвих навичок та створення можливостей впливу на основні негативні наслідки вживання дітьми ПАР, а саме - вживання зі шкідливими наслідками.

Розроблена комплексна система заходів протиалкогольного та протинаркотичного спрямування для шкільної молоді включає в себе щонайменше 3 основні складові. Ці складові направлені безпосередньо на дитячі контингенти, на вчителів і, що є принциповою відмінністю, на батьків. Кожна з даних цільових груп потребує використання власного набору технологічних прийомів. Це, в свою чергу, дозволяє повною мірою скористатися перевагами, які здатна надати школа як унікальне місце, в якому зустрічаються інтереси батьків, дітей і освітян.

Кожний з напрямків профілактичної діяльності у розробленій системі представлений у формі модулів профілактичного спрямування:

Модуль 1. Технологія проведення профілактичного тренінгу в умовах шкільного середовища. Профілактика алкогольних та наркотичних проблем.

Модуль 2. Профілактичні дії на робочому місці серед персоналу загальноосвітніх навчальних закладів. 
Модуль 3. Батьківська компетентність або підказки батькам. Профілактика алкогольних та наркотичних проблем серед дітей.

Модуль 4. “Моє здоров'я... Моє рішення... Мій вибір... Профілактика алкогольних та наркотичних проблем серед учнів". Модуль доповнений 12 робочими зошитами для учнів 1-12 класів.

1. Програма профілактики на робочому місці. Ефективна профілактична робота в школі починається зі складних за своєю структурою профілактичних програм на робочому місці, які концентрують свої зусилля на початку саме на педагогічному та технічному персоналові. Тільки після досягнення необхідного якісного рівня базової інформованості працівників школи можна перейти до наступного етапу - залучення батьків та учнів. Програми на робочому місці, як показує український та світовий досвід, дозволяють швидко, економічно та ефективно досягти необхідного рівня інформованості в робочих колективах, що має особливе значення для колективів шкіл.

2. Профілактичний курс для батьків учнів. Зміст даного посібника представлений у формі 16 методичних розробок профілактичних занять для батьків, рекомендований для використання класними керівниками в системі батьківських зборів. Тематичний матеріал викладений в інтерактивній формі і корисний для батьків дітей різних вікових груп. Ведучий має можливість скористатися рекомендаціями (зазначеними в розділі “Тематичний план коротких профілактичних інтервенцій”), що вказують на оптимальний навчальний рік дитини, в якому буде доцільно проводити дане профілактичне заняття з ії батьками.

Суттєвою відмінністю даного профілактичного курсу є застосування сучасної, нової для української школи, форми профілактичної роботи, - “короткі інформаційні та навчальні інтервенції”, які стали поширеним інструментом протинаркотичної діяльності у десятках країн світу. Така форма профілактичної роботи вдало вписується в систему батьківських зборів, не перевантажує працю вчителя i, головне, позитивно сприймається батьками, оскільки має певні для них переваги на відміну відлекцій та тренінгів. А саме: навчальні та інформаційні інтервенції можуть тривати від 5 до 40 хв; інформування невелике за обсягом. Під час коротких інтервенцій, на яких батьки взаємодіють один з одним та з ведучим, вони отримують профілактичну інформацію у формі інформаційних листків для самостійного вивчення, “профілактичні підказки" з метою зосередження уваги батьків на головних питаннях теми. Враховуючи специфіку батьківської аудиторії, короткі профілактичні інтер- венції вдало вписуються в систему батьківських зборів.

3 метою отримання інформованої згоди від батьків на проведення профілактичної роботи в школі з їхніми дітьми та 3 ними, між батьками та адміністрацією школи в 1 класі укладається договір, складений керівництвом шкільного закладу, та проводиться ознайомлювальна конференція щодо завдань та змісту профілактичної.

3. Виховна профілактична протинаркотична та протиалкогольна програма, зорієнтована на учнів 1-12 класів. Методики, представлені в практичному курсі для учнів, ефективні для досягнення цілей і виконання завдань навчання здорового способу життя на засадах розвитку життєвих навичок. Профілактичне навчання відбувається через практику дії.

- Уроки для учнів першого ступеня навчання мають профілактичне спрямування з акцентом на понятті “Моє здоров' я" (навички підтримки здорового способу життя). Учні вчаться відрізняти корисне від шкідливого, безпечне від небезпечного.

- Уроки для учнів другого ступеня навчання мають профілактичне спрямування з акцентом на понятті “Моє рішення” (навички прийняття рішення та критичне мислення). Учні пізнають себе і те, що на них впливає. Аналізуючи інформацію про психоактивні речовини, вони вчаться розрізняти факти від міфів, приймати усвідомлені рішення в ситуаціях ризику.

- Уроки для учнів третього ступеня навчання мають профілактичне спрямування з акцентом на понятті “Мій вибір" (самовизначення та власна життева позиція). Учні аналізують різні “сценаріі”” життя людей, які обрали шлях вживання наркотиків чи алкоголю. Визначаються 3 власною життєвою позицією, цінностями. Вчаться відстоювати свої переконання та погляди. Будують свій власний “сценарій життя" на основі питань: хто я $\epsilon$, і ким я хочу бути?

Загальні питання профілактичної роботи для всіх цільових груп:

- Алкоголь та наслідки його вживання.

· Наркотики та наслідки їх вживання.

- Факти про ВІЛ/СНІД. Особиста профілактика.

- Хибні уявлення щодо вживання психоактивної речовини.

- Фактори ризику щодо появи наркотичних та алкогольних проблем.

- Фактори захисту від наркотичних та алкогольних проблем.

- Законодавство щодо наркотиків.

Особливі питання для роботи з методистами інститутів післядипломного навчання:

- Особливості проведення профілактичного тренінгу. - Організація та підготовка профілактичного тренінгу. 
- Вміння та знання ефективного тренера.

- Інтерактивні методи роботи з групою.

. Складні ситуації під час тренінгу та шляхи їх подолання.

. Специфіка дитячої аудиторії. Ефективні методи профілактичної роботи.

- Специфіка підліткової аудиторії. Ефективні методи профілактичної роботи.

. Специфіка дорослої аудиторії (батьки учнів початкових класів). Ефективні методи профілактичної роботи.

- Специфіка дорослої аудиторії (батьки учнів середніх та старших класів). Ефективні методи профілактичної роботи.

Особливі питання профілактичної роботи із працівниками шкільного закладу:

- Поняття про програму профілактики на робочому місці.

- Розробка та впровадження політики закладу освіти щодо профілактики наркотичних та алкогольних проблем серед працівників шкільного середовища.

- Оцінка працівниками рівня власного вживання алкоголю:

- спеціальні тести для самооцінки;

- поняття про 1 стандартну дозу;

- поняття про помірне та ризиковане вживання алкоголю.

Особливі питання для профілактичної роботи 3 батьками учнів:

· Хибні уявлення батьків, які заважають ефективній профілактиці наркотичних та алкогольних проблем у дітей.

- Соціальні та особистісні фактори ризику щодо появи наркотичних та алкогольних проблем у дітей.

- Сімейна політика (правила) щодо вживання психоактивних речовин, як фактор захисту від наркотичних та алкогольних проблем у дитини.

- Задоволення важливих (духовних та соціальних) потреб дитини, як фактор захисту від наркотичних та алкогольних проблем.

. Стиль виховання дитини, як фактор захисту від наркотичних та алкогольних проблем.

- Особистісний захист від наркотичних та алкогольних проблем. Корисні навички: розвиток самоповаги, впевненості в собі та формування навички самоконтролю.

- Особистісний захист від наркотичних та алкогольних проблем. Корисні вміння: розвиток вміння протистояти соціальному тиску, приймати рішення, критично мислити та ефективно спілкуватися.

- Тренуємось вдома (вправи на розвиток корисних вмінь та навичок).

- Ефективне спілкування з дитиною (що не варто робити під час спілкування).

. Як розмовляти з дитиною про алкоголь, про наркотики, про ВІЛ/СНІД.

- Ознаки раннього вживання наркотичних речовин.

Особливі питання профілактичної роботи з учнями 1-12 класів представлено в таблиці 1.

Таблиця 1. Особливі питання профілактичної роботи з учнями 1-12 класів

\begin{tabular}{|c|c|}
\hline $\begin{array}{c}\text { Корисні } \\
\text { знання }\end{array}$ & $\begin{array}{l}\text { Поняття про безпеку та небезпеку } \\
\text { Поняття про ризик та захист } \\
\text { Поняття про фізичне, психічне та духовне здоров’я } \\
\text { Настрій. Шляхи подолання поганого настрою } \\
\text { Поняття про небезпечні знання; небезпечні речовини; небезпечні ситуації } \\
\text { Правила поводження в небезпечних ситуаціях } \\
\text { Ризик. Соціальні та особистісні фактори ризику появи наркотичних та алкогольних проблем } \\
\text { Хибні уявлення щодо вживання алкоголю та наркотиків } \\
\text { Задоволення та хвороба } \\
\text { Поняття про дружбу, кохання, успіх і залежність } \\
\text { Гроші як фактор ризику } \\
\text { Поняття про соціальний тиск } \\
\text { Безпечні захоплення та інтереси } \\
\text { Реклама та їі мета }\end{array}$ \\
\hline $\begin{array}{l}\text { Адекватне } \\
\text { ставлення }\end{array}$ & $\begin{array}{l}\text { До: } \\
\text { - власного здоров’я; } \\
\text { - власної унікальності; } \\
\text { - власного вибору; } \\
\text { - власного рішення; } \\
\text { - вживання психоактивних речовин; } \\
\text { - власних емоцій та почуттів; } \\
\text { - життєвих негараздів; } \\
\text { - способів особистісного захисту }\end{array}$ \\
\hline
\end{tabular}


Продовження табл. 1

\begin{tabular}{|c|l|}
\hline $\begin{array}{c}\text { Корисні } \\
\text { вміння }\end{array}$ & Протистояння соціальному тиску \\
& $\begin{array}{l}\text { Криймання правильного рішення } \\
\text { Критичне мислення } \\
\text { Ефективне спілкування }\end{array}$ \\
\hline Корисні & Самоповага \\
навички & Самоконтроль \\
& Впевненість \\
\hline
\end{tabular}

Висновок. Таким чином, кожний модуль має свої завдання, цільову групу, форму і методи реалізації, структуру та особливості проведення. Водночас програмні модулі пов'язані між собою загальною ідеєю системи профілактики, що забезпечує їі комплексність. Комплекс профілактичних інформаційно-

\section{Лiтература}

1. Лист Інституту інноваційних технологій змісту освіти МОН України №14/18-1274 від 30.03.2010.

2. Молодь за здоровий спосіб життя : щорічна доповідь Президенту України, Верховній Раді України, Кабінету Міністрів України про становище молоді в Україні (за підсумками 2009 р.) / Міністерство України у справах сім'ї, молоді та спорту, Державний інститут розвитку сім'ї та молоді. -К. : ТОВ “Основа”, 2010.

3. Журавель Т. В. Використання інтерактивних методів та мультфільмів у профілактиці ризикованої поведінки : ме- навчальних матеріалів дозволяє батькам та вчителям дотримуватися єдиного підходу в профілактиці вживання ПАР дитиною.

Враховуючи ефективність апробації даної системи в пілотних регіонах, зараз проводиться робота щодо впровадження вищезазначених заходів на державному рівні.

тодичний посібник для спеціалістів, які працюють 3 бездоглядними та безпритульними дітьми і підлітками / Т. В. Журавель, Т. Л. Лях, О. М. Нікітіна. -К., 2010. - 37 с.

4. Рівень і тенденції поширення тютюнокуріння, вживання алкоголю та наркотичних речовин серед учнівської молоді України / [О. М. Балакірєва (кер. авт. кол.), Т. В. Бондар, Н. О. Рингач та ін.]. -К. : УІСД ім. О. Яременка, 2008. - 152 с. 5. Зріз наркотичної ситуації в Україні (дані 2010 року) / [А. М. Вієвський, М. П. Жданова, С. В. Сидяк та ін.]. - Київ, 2011. -22 c. 